\title{
Petrology of Group 2 Kimberlite-Olivine lamproite (K2L) series from the Kostomuksha area, Karelia, N.W. Russia
}

\author{
Mahotkin, I.L.
}

De Beers Centenary (Russia), Ul. Tverskaya 22a, Moscow, 103050, Russia

Ultrapotassic ultramafic rocks from the Kostomuksha area were first described as lamproites by Proskuryakov (1989). These intrusions (50 dykes and 2 bodies of explosive breccia) are situated in the centre of the Archaean Karelian craton along the meridian fracture zone. The dykes occur in three clusters with each of them being 12-18 sq. km in extent. Some of the occurrences are diamondiferous (Zhuravlev et al., 1995).

In this study 7 rock samples from 5 dikes occurring in $0.5 \mathrm{~km}$ line within the southern quarry of the Kostomuksha iron-ore deposit were investigated. These dykes (0.5-4 $\mathrm{m}$ in width) intrude the Late Archaean Lopian greenstone crystalline schists and ferruginous quartzites. The age of the dykes is 1231-1241 Ma accordingly to $\mathrm{Rb}-\mathrm{Sr}$ and $\mathrm{Sm}-\mathrm{Nd}$ mineral isochron data (Nikitina at al., 1995).

All the rocks investigated (table below) are ultramafic $\left(\mathrm{SiO}_{2}=38-43\right.$ wt. \%), ultrapotassic $\left(\mathrm{K}_{2} \mathrm{O} / \mathrm{Na}_{2} \mathrm{O}=18-32\right)$ and peralkaline (P.I. $\left.=1.09-1.67\right)$. Normative acmite $(\mathrm{ac}=1.4-2.2 \mathrm{wt} \%)$ and potassium metasillicate $(\mathrm{ks}=0.02-4.43 \mathrm{wt} \%)$ are in their $\mathrm{CIPW}$-norms.

\begin{tabular}{|l|l|l|l|l|l|l|l|}
\hline Samples & $1 / 95$ & $2 / 95$ & $3 / 95$ & $4 / 95$ & $5 / 95$ & $7 / 95$ & $8 / 95$ \\
\hline $\mathrm{Wt} \% \%$ & & & & & & & \\
$\mathrm{SiO}_{2}$ & 39,05 & 38,2 & 40,85 & 38,60 & 42,65 & 39,50 & 41,00 \\
$\mathrm{TiO}_{2}$ & 2.25 & 2,15 & 2,45 & 2,7 & 2,48 & 3,6 & 3,65 \\
$\mathrm{Al}_{2} \mathrm{O}_{3}$ & 4,66 & 4,43 & 4,3 & 4,66 & 5,18 & 4,65 & 6,25 \\
$\mathrm{Fe}_{2} \mathrm{O} 3$ & 8,95 & 8,45 & 9,0 & 9,45 & 9,67 & 9,50 & 9,28 \\
$\mathrm{MnO}$ & 0,2 & 0,2 & 0,18 & 0,15 & 0,36 & 0,14 & 0,12 \\
$\mathrm{MgO}$ & 22,36 & 23,14 & 22,31 & 21,96 & 20,21 & 17,25 & 15,96 \\
$\mathrm{CaO}$ & 5,97 & 6,49 & 5,88 & 6,05 & 3,24 & 7,64 & 6,88 \\
$\mathrm{Na}_{2} \mathrm{O}$ & 0,24 & 0,17 & 0,27 & 0,27 & 0,19 & 0,26 & 0,23 \\
$\mathrm{~K}_{2} \mathrm{O}$ & 4,32 & 5,08 & 4,74 & 5,06 & 5,77 & 6,77 & 7,29 \\
$\mathrm{P}_{2} \mathrm{O}_{5}$ & 0,96 & 0,9 & 0,96 & 1,22 & 1,07 & 2,26 & 1,94 \\
$\mathrm{H} 2 \mathrm{O}-$ & 2,45 & 1,47 & 1,57 & 2,02 & 2,57 & 2,16 & 2,1 \\
$\mathrm{H} 2 \mathrm{O}+$ & 4,9 & 4,71 & 4,97 & 5,02 & 4,02 & 3,04 & 2,08 \\
$\mathrm{CO} 2$ & 3,19 & 4,11 & 1,98 & 2,59 & 2,09 & 2,79 & 2,46 \\
$\mathrm{~F}$ & 0,21 & 0,18 & 0,21 & 0,26 & 0,28 & 0,32 & 0,34 \\
\hline $\mathrm{Total}$ & 99,7 & 99,68 & 99,67 & 100,01 & 99,76 & 99,88 & 99,58 \\
\hline$\# \mathrm{mg}$ & 0,849 & 0,860 & 0,848 & 0,839 & 0,825 & 0,803 & 0,795 \\
$\mathrm{~K}_{2} \mathrm{O} / \mathrm{Na} 2 \mathrm{O}$ & 18,0 & 29,9 & 17,6 & 18,7 & 30,4 & 26,0 & 31,7 \\
$\mathrm{P.I.}$ & 1,09 & 1,30 & 1,30 & 1,27 & 1,27 & 1,67 & 1,32 \\
\hline $\mathrm{ppm}$ & 1395 & 1630 & 1280 & 1160 & 1740 & 570 & 450 \\
$\mathrm{Ni}$ & 100 & 91 & 94 & 92 & 107 & 74 & 70 \\
$\mathrm{Co}$ & 1075 & 1086 & 1031 & 1007 & 918 & 399 & 376 \\
$\mathrm{Cr}$ & 69,38 & 112,94 & 98,69 & 93,05 & 63,61 & 103,89 & 102,06 \\
\hline $\mathrm{La} / \mathrm{Yb}) \mathrm{N}$ & 13,95 & 17,91 & 13,62 & 12,61 & 16,26 & 7,70 & 6,43 \\
$\mathrm{Ni} / \mathrm{Co}$ & 1 & & & \\
\hline
\end{tabular}

There are four different petrographic varieties of the Kostomuksha rocks:

(1) Monticellite-phlogopite kimberlites (samples $2 / 95$ \& 4/95) consisting of olivine macrocrysts and phenocrysts (25-30 vol.\%), microphenocrysts laths of phlogopite (35-40 vol.\%), poikiliticaly 
enclosing monticellite, apatite and spinel and groundmass of these latter three minerals plus calcite and saponite. Monticellite is replaced by serpentine and hydrogarnet.

(2) Phlogopite-kimberlites (samples $1 / 95$ \& 3/95) consisting of olivine macrocrysts and phenocryst (25-30 vol.\%) and microphenocrysts phlogopite laths (30-40 vol.\%), poikiliticaly enclosing apatite, some tabular crystals (1-2 vol.\%), which are probably melilite replaced by calcite, and spinel in a groundmass of clinopyroxene ( 3 vol.\%) partly replaced by amphibole (3-5 vol.\%) plus primary calcite (5-7 vol.\%), secondary serpentine (5 vol.\%) and clay-mineralised phlogopite (15 vol.\%).

(3) Leucite-olivine lamproites (sample 5/95) consisting of olivine phenocrysts (20-25 vol.\%), pseudoleucite (20-25 vol.\%), groundmass phlogopite (10-15 vol.\%), clinopyroxene (1-3 vol.\%), sanidine, saponite and talc.

(4) Phlogopite lamproites (samples: 7/95 \& 8/95) consisting of olivine phenocrysts (5 vol.\%), pseudoleucite microphenocrysts (0.5-2 vol.\%), groundmass phlogopite (55-65 vol.\%), clinopyroxene (2-5 vol.\%), sanidine (1 vol.\%), amphibole (1 vol.\%), potassic saponite, apatite, rutile and other opaque minerals. Kalsilite also occurs probably as reaction product after leucite breakdown.

Compositions of the micas and clinopyroxenes from both kimberlites and lamproites exhibit intermediate trends between those for Group 2 kimberlites and lamproites. The micas are aluminous-poor phlogopite $\left(9-1 \mathrm{wt} \% \mathrm{Al}_{2} \mathrm{O}_{3}\right)$. They exhibit an extremely wide range of FeO (7-17 wt.\%) and $\mathrm{TiO}_{2}$ (1-6.5 wt.\%) values. The clinopyroxenes are Al-deficient and Si-rich, Ti-rich diopside enriched in fassaite component. The amphiboles are relatively poor $\mathrm{TiO}_{2}(1.6-4 \mathrm{wt} . \%)$ richterite. They exhibit a wide range of $\mathrm{Na} / \mathrm{K}$ ratios which are similar to those for MARID amphiboles.

The CIPW-norms of the Kostomuksha kimberlites and lamproites are shown in the phase diagrams (fig.1), depicting forsterite. kalsilite and quartz as end members (Yoder,1986). The monticellite-phlogopite kimberlite compositions fit into the Fo-Ph-Di-Ak subsystem of Yoder's normative tetrahedron. The phlogopite kimberlites fit into the Fo-Ph-Sa-Di subsystem whereas all lamproites fit into the Lc-Ph-Sa subsystem of this tetrahedron. The positions of the monticellitephlogopite and phlogopite kimberlite compositions, in accordance with the high pressure phase relationship indicated by Foley (1994), are close to the peritectic of phlogopite lherzolite at 50-55 Kbars whereas the lamproite compositions are closed to those at 40 Kbars.

The Kostomuksha kimberlites and lamproites have similar REE patterns in accordance with kimberlites and olivine lamproites worldwide. They are enriched in LREE $\left(\operatorname{La}_{N}=1000\right)$ and depleted in TREE $\left(\mathrm{Yb}_{\mathrm{N}}=7-13\right)$. Multi-element patterns for the Kostomuksha rocks are different, however, from those of the most lamproites (fig. 2). These patterns are similar to those of mica kimberlites from the Archangelsk region and Argyle lamproites (Mahotkin et al.,1991). Sr and Nd isotope compositions of the Kostomuksha rocks $\left(\varepsilon_{\mathrm{Sr}}=+30\right.$ and $\left.\varepsilon_{\mathrm{Nd}}=-9\right)$ are plotted on $\mathrm{Sr}-\mathrm{Nd}$ isotope diagram in between Group I and Group II kimberlite fields but are coincident with the field of melilitephlogopite kimberlites from the Archangelsk region and Argyle lamproites (personal data).

In conclusion this study indicates the following:

(1)Late Proterozoic Group 2 kimberlites and olivine-phlogopite lamproites presumably of similar age occur together in the Kostomuksha area. They form a single geochemical rock series here referred to as the $\mathrm{K} 2 \mathrm{~L}$ series.

(2)The Kostomuksha kimberlite and lamproite melts originated from the same lithospheric mantle source as a result of phlogopite-garnet lherzolite melting at depths of $50 \mathrm{Kbar}$ in the case of the kimberlites and $40 \mathrm{Kbar}$ in the case of the lamproites. $\mathrm{CO} / \mathrm{H}_{2} \mathrm{O}$ ratio in fluids during the melting process was constant but the fluids were probable a little enriched in water.

(3)The ancient lithospheric mantle in the Kostomuksha area was previously enriched in REE as indicated by the Sr and Nd systematics. The enrichment style was similar to that at Argyle and at Archangelsk with respect to low Ti kimberlites. 

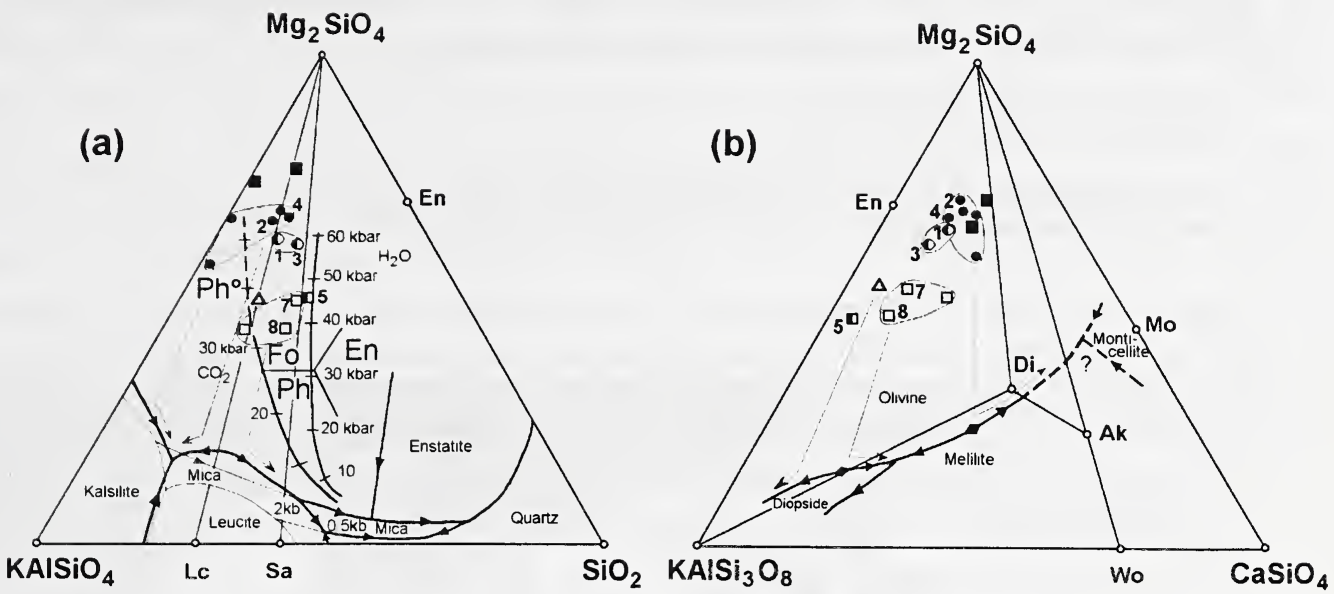

Fig. 1 (a,b) Kostomuksha: •- Mo-Ph kimberlites; 0 -Ph kimberlites; $\mathbf{v}$ - Lc-Ol lamproites; $\square$ - Phl lamproites Archangelsk: - Mo-Ph kımberlites (pipes: Pionerskaya, Lomonosovskaya); $\Delta$-Ks-Ph kimberlites (lamproites), Karpinskiy-l pipe

(a) - line and perirtectic point $\mathrm{Ol}+E n+P h+L q$ are after of S. Foley (1992)

(b) -phase boundarles are shown for $A b+L n+F o$ system after of H.S. Yoder (1979)

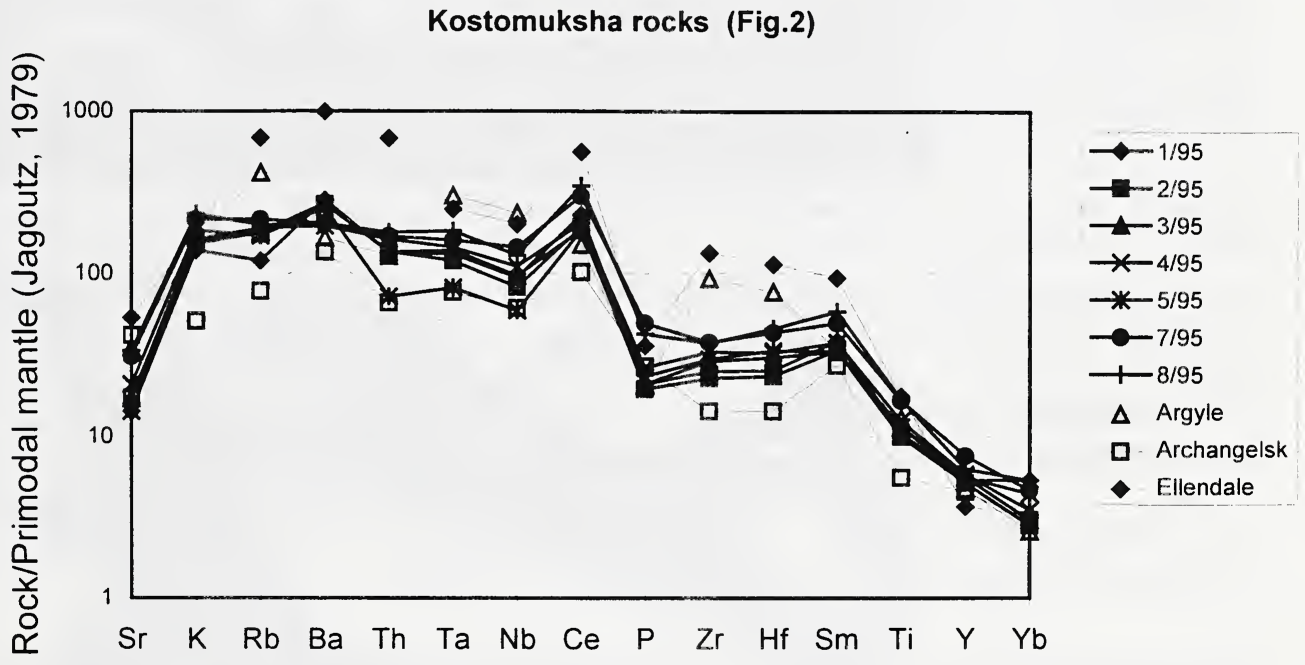

\section{References}

Proskuryakov, V.V., Uvadiev, L.I., and Voinova, O.A., 1990, Lamproites of the Karelo-Kola region: Transactions USSR Acad. Sci. Vol. 314, p. 940-943.

Zhuravlev, V.A., Shulga, T.F., and Ushkov, V.V., 1995, Diamond-Bearing Lamproites of the Kostomuksha region of Karelia: Procced. 2d Int. Symp. "Mineral Resources of Russia: Diamond and Gold", St. Petersburg, VSEGEI, p. 37-40. Nikitina, L.P., 1995, Mineralogy and isotope geochemistry of the Kostomuksha lamroites: Abstracts. Conf. "Precious metals and diamond in the Northern European Russia", Petrozavodsk, p. 20-21.

Yoder, H.S., 1986, Potassium-rich Rocks: Phase Analysis and Heteromorphic Relations: Jour. Petrology. Vol. 27, Part 5, p. 1215-1228.

Foley, S., 1992, Petrological characterization of the source components of potassic magmas: geochemical and experimental constraints: Lithos, Vol. 28, p. 187-204.

Mahotkin, I.L., Bogatikov, O.A, and Kononova, V.A., 1991, Comparative petrochemistry of lamproites and their heterogeneity: In book: Lamproites. Nauka, Moscow, p. 161-173. 